\title{
IMPLEMENTASI MODEL PEMBELAJARAN QUANTUM DENGAN METODEDISKUSI UNTUK MENINGKATKAN AKTIVITAS DAN HASIL BELAJAR FISIKA SISWA SMPN 2 LINGSAR TAHUN AJARAN 2014/2015
}

\author{
Ibrohim Mirgoni*, Hairunnisyah Sahidu, Hikmawati \\ Program Studi Pendidikan Fisika \\ FKIP Universitas Mataram \\ Email: baim.gon@gmail.com
}

\begin{abstract}
This research is a classroom action research which aims to increase physical activity and learning outcomes of students SMPN 2 Lingsar the academic year 2014/2015. The subjects in this study VIII5 classes totaling 40 people. Implementation of classroom action research was conducted in two cycles with each cycle consisting of four stages: planning, implementation, observation and evaluation, and reflection. Student learning activity data obtained through observation, while data on student learning outcomes obtained through the administration of the test at the end of each cycle. Based on the results of the evaluation cycle I obtained an average score of student learning activity is 11 , which is in the category fairly active. The average value of the class in the first cycle of 73.95 with $78.95 \%$ classical completeness. Results of the evaluation in the second cycle to the average score is 14.6 students' learning activities that are in the active category. The average value of the class in the second cycle of 78.10 with $89.19 \%$ classical completeness. The average score of student learning activity increased from the first cycle to the second cycle of 3.6, the learning outcomes of students increased by 4.15 , while the classical completeness increased by $10.24 \%$. Based on the results of this study concluded that the implementation of the learning model Quantum with discussion method can increase physical activity and learning outcomes VIII 5 grade students of SMPN 2 Lingsar the academic year 2014/2015.
\end{abstract}

Keywords: QuantumLearning Model, Method Discussion, Learning Activity, Learning Outcomes

\section{Pendahuluan}

Sains (IPA) merujuk kepada sebuah sistem untuk mendapatkan pengetahuan yang menggunakan pengamatan dan eksperimen untuk menggambarkan dan menjelaskan fenomena-fenomena yang terjadi di alam. IPA merupakan ilmu pengetahuan yang banyak membahas tentang fenomena alam lebih khususnya yaitu ilmu fisika, yang kumpulan pengetahuannya sebagian besar berupa konsep yang bersifat abstrak, sehingga diperlukan pemahaman yang lebih mendalam melalui suatu kegiatan penyelidikan/percobaan. Kegiatan penyelidikan dalam pembelajaran fisika dapat memberikan kesempatan pada siswa untuk mengembangkan keterampilan yang dimilikinya sehingga dapat meningkatkan kualitas belajar siswa.

Proses pembelajaran yang dilakukan di sekolah haruslah efektif agar tujuan pembelajaran yang diinginkan dapat tercapai. Begitu pula dengan pembelajaran fisika yang pelaksanaannya sebaiknya berpusat pada siswa agar dapat memperoleh keberhasilan dalam pembelajaran. Keberhasilan proses pembelajaran bukan hanya ditentukan oleh aktivitas guru dalam mengajar, melainkan aktivitas belajar siswa selama proses pembelajaran berlangsung.

Berdasarkan hasil observasi selama melaksanakan Praktek Pengalaman Lapangan (PPL) di SMPN 2 Lingsar, didapatkan bahwa metode pembelajaran fisika yang diterapkan masih berorientasi pada guru dan kurang memperhatikan aktivitas siswa. Guru menyampaikan materi-materi pelajaran dan siswa dituntut untuk menghafal dan mencatat semua pengetahuannya tanpa memberikan sesuatu yang bermakna. Pembelajaran seperti ini memang terbukti berhasil membuat siswa mengingat informasi yang diajarkan dalam jangka pendek, akan tetapi tidak dapat membekali siswa dalam mengingat informasi dan menyelesaikan masalah untuk jangka waktu yang panjang. Selain itu, kesiapan siswa dalam menerima pelajaran masih dianggap kurang baik, karena dalam proses penerimaan informasi siswa memiliki semangat dan motivasi yang kurang. Kurangnya semangat dan motivasi belajar siswa sangat berdampak pada hasil dan aktivitas belajar siswa.

Berdasarkan hasil wawancara dengan siswa didapatkan bahwa pelajaran fisika masih dianggap sangat sulit. Hal ini disebabkan karena banyaknya konsep dan rumus fisika yang memerlukan analisis dan perhitungan matematis. Selain itu, hasil wawancara dengan guru bidang studi IPA di SMP Negeri 2 Lingsar bahwa semua kelas yang ada diklasifikasikan berdasarkan tingkat kemampuan siswa. Siswa yang memiliki kemampuan tinggi dikelompokkan dalam kelas unggulan, sedangkan siswa dengan kemampuan menengah ke bawah dikelompokkan menjadi kelas reguler. Kelas reguler mendapat perlakuan yang sama dengan kelas unggulan, namun keaktifan, daya ingat materi, dan 
pemahaman konsep siswa cukup rendah sehingga nilai yang ada pada kelas reguler jauh di bawah KKM.

Salah satu alternatif pemecahan masalah di atas yang harus diterapkan oleh guru adalah menggunakan model pembelajaran yang tepat sehingga aktivitas dan hasil belajar siswa akan meningkat. Salah satu model pembelajaran yang dapat mengaktifkan siswa, mengembangkan kemampuan berfikir kritis, dan berfikir kreatif adalah menggunakan model pembelajaran Quantum.

Beberapa penelitian yang sudah dilakukan dengan model pembelajaran Quantum telah terbukti dapat meningkatkan hasil belajar Fisika siswa diantaranya penelitian yang dilakukan oleh Juliani dan Rahmatsyah [1] pada mata kuliah pengukuran dan alat ukur fisika. Aktivitas dan hasil belajar meningkat antara $25 \%$ sampai $35 \%$ dari hasil belajar sebelumnya. Penelitian Simarmata [2] Menerapkan model pembelajaran Quantum pada kelas XI dengan pokok bahasan fluida mengalami peningkatan hasil belajar Fisika sebesar 42,7 \% sehingga siswa tuntas secara klaksikal 85,5\%.

Sesuai dengan permasalahan yang telah dirumuskan di atas, maka tujuan penelitian ini adalah untuk meningkatkan aktivitas dan hasil belajar fisika siswa melalui implementasi model pembelajaran Quantum dengan metode Diskusi pada kelas VIII SMP Negeri 2 Lingsar tahun ajaran 2014/2015. Hasil penelitian ini diharapkan bermanfaat bagi pengembangan kegiatan pembelajaran dalam mata pelajaran fisika serta dapat bermanfaat bagi guru, siswa, sekolah serta bagi peneliti yang ingin mengambil kajian yang sama guna meningkatkan meningkatkan aktivitas dan hasil belajar fisika siswa.

\section{Metode Penelitian}

Jenis penelitian adalah penelitian tindakan kelas (Classroom Action Research) yang didasarkan atas upaya meningkatkan hasil, yaitu lebih baik dari sebelumnya. Penelitian tindakan kelas merupakan suatu pencermatan terhadap kegiatan belajar berupa sebuah tindakan, yang sengaja dimunculkan dan terjadi dalam sebuah kelas secara bersama [3].

Subyek penelitian ini adalah siswa kelas $\mathrm{VIII}_{5}$ SMP Negeri 2 Lingsar tahun ajaran 2014/2015, sedangkan obyek penelitian adalah aktivitas belajar dan hasil belajar siswa. Penelitian ini dilaksanakan mulai bulan November 2014 sampai dengan Mei 2015, bertempat di SMPN 2 Lingsar. Faktor yang diteliti adalah faktor siswa, yaitu dengan melihat peningkatan aktivitas dan hasil belajarnya setelah menggunakan model pembelajaran Quantum dengan metode diskusi.

Prosedur kegiatan penelitian dilakukan dalam lima tahap yaitu:

\section{Perencanaan}

Pada tahap perencanaan, peneliti mempersiapkan segala sesuatu yang dibutuhkan pada saat penelitian, di antaranya : (1) Menyusun jadwal penelitian; (2) Melakukan observasi di SMP Negeri 2 Lingsar pada kelas VIII5; (3) Peneliti melakukan telah kurikulum fisika SMP dan penentuan materi pembelajaran dalam penelitian; (4) Mensosialisasikan model pembelajaran Quantum kepada guru pengampu; (5) Mengembangkan tujuan pembelajaran berdasarkan indikator; (6) Membuat rencana pembelajaran (RPP) dan lembar kerja siswa (LKS); (7) Membuat lembar observasi untuk mengamati kegiatan siswa selama proses pembelajaran; (8) Menyiapkan soal tes evaluasi berbentuk pilihan ganda beserta kunci jawabannya; (9) Membuat daftar nama kelompok siswa yakni membagi siswa menjadi beberapa kelompok dengan masing-masing kelompok terdiri atas 5-6 orang siswa dengan tingkat kemampuan yang heterogen dan jenis kelamin yang berbeda-beda; (10) Mengkonsultasikan instrumen (tes) kepada dosen pembimbing; (11) Merevisi/memperbaiki instrumen; (12) Melakukan uji coba instrumen pada kelas yang memiliki karakteristik yang sama dengan subjek yang diteliti; (13) Menganalisis hasil uji coba instrumen yang meliputi validitas, reliabilitas, tingkat kesukaran, dan daya pembeda sehingga layak dipakai untuk tes akhir.

\section{Pelaksanaan Tindakan}

Tahap tindakan merupakan implementasi (pelaksanaan) dari semua rencana yang telah dibuat. Tahapan yang berlangsung di kelas ini merupakan realisasi dari segala teori pendidikan dan teknik mengajar yang sudah dipersiapkan sebelumnya.

\section{Observasi dan Evaluasi}

Pada tahap ini dilakukan proses observasi secara kontinu setiap berlangsungnya pelaksanaan tindakan dengan menggunakan lembar observasi. Selain itu dilakukan pengisian lembar observasi oleh observer untuk mengetahui aktivitas belajar siswa, sedangkan pada tahap evaluasi, siswa diberi tes evaluasi pada akhir tiap siklus.

\section{Refleksi}

Refleksi dilakukan pada akhir tiap siklus. Pada tahap ini, peneliti mengkaji pelaksanaan dan hasil yang diperoleh dalam pemberian tindakan tiap siklusnya. Sebagai acuan dalam tahapan ini adalah hasil observasi dan evaluasi. Hasil ini digunakan sebagai dasar untuk memperbaiki serta menyempurnakan perencanaan dan pelaksanaan tindakan pada siklus selanjutnya. Indikator keberhasilan dalam penelitian ini dikatakan berhasil jika memenuhi; (1) Aktivitas siswa dalam pembelajaran dengan penerapan model pembelajaran Quantum dengan metode diskusi minimal berada pada konversi nilai $14,58 \leq \bar{x}<18,74$ dengan kriteria aktif 
[4]. (2) Hasil belajar kognitif siswa mencapai ketuntasan klasikal $\geq 85 \%$ dengan kriteria ketuntasan minimal per siswa adalah 75 .

\section{Hasil dan Pembahasan}

Pada penelitian tindakan kelas ini, pembelajaran dilaksanakan dalam dua siklus dengan menerapkan model pembelajaran Quantum metode Diskusi di kelas VIII5 SMPN 2 Lingsar tahun ajaran 2014/2015. Pada siklus I sebanyak 2 kali pertemuan, pelaksanaan kegiatan belajar mengajar disesuaikan dengan RPP yang dibuat berdasarkan sintaks model pembelajaran Quantum metode diskusi dengan memperhatikan hasil pengamatan pada saat observasi awal. Materi pembelajaran yang digunakan adalah materi Indra Penglihatan dan Alat Optik. Perbandingan aktivitas siswa pada siklus I dan siklus II dapat dilihat pada diagram 1.1 di bawah ini:

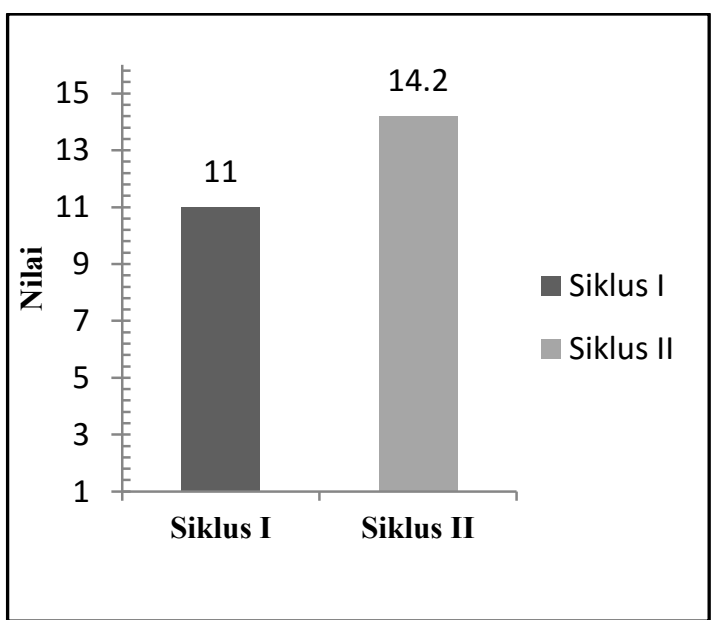

Gambar 1.1Diagram Aktivitas Belajar Siswa Siklus I dan Siklus II

Diagram hasil rata-rata kelas dan ketuntasan klaksikal siklus I dan siklus II dapat dilihat pada diagram 1.2 sebagai berikut:

Pada siklus 1 diperoleh nilai rata-rata siswa sebesar 73,95 dengan ketuntasan klasikal mencapai 78,95 \%, sedangkan nilai rata-rata aktivitas belajar siswa sebesar 11 yang berada pada kategori cukup aktif. Hasil ini menunjukkan bahwa hasil belajar siswa belum mencapai indikator keberhasilan karena siswa yang memperoleh nilai $\geq 75$ masih berada di bawah $85 \%$. Selain itu, nilai rata-rata aktivitas belajar siswa pada siklus I belum mencapai indikator keberhasilan karena masih berada pada kategori cukup aktif.

Aktivitas dan Hasil belajar siswa pada siklus I masih belum mencapai indikator keberhasilan. Hal ini disebabkan karena masih ada siswa yang tidak mengikuti kegiatan pembelajaran dengan baik, siswa masih belum bisa memahami permasalahan yang ditampilkan oleh guru, belum bisa mendefinisikan tugas belajar yang diberikan oleh guru, belum terbiasa dalam melakukan percobaan atau

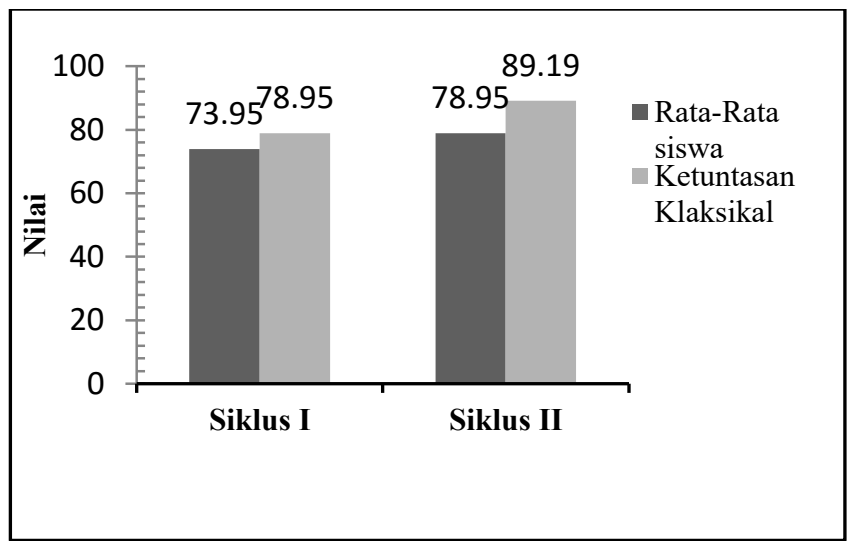

Gambar 1.2 Diagram Hasil Rata-Rata Kelas dan KetuntasanKlasikal Siklus I dan Siklus II

Diagram hasil belajar ranah afeksi dan psikomotor siklus I dan II dapat dilihat pada diagram 1.3 sebagai berikut:

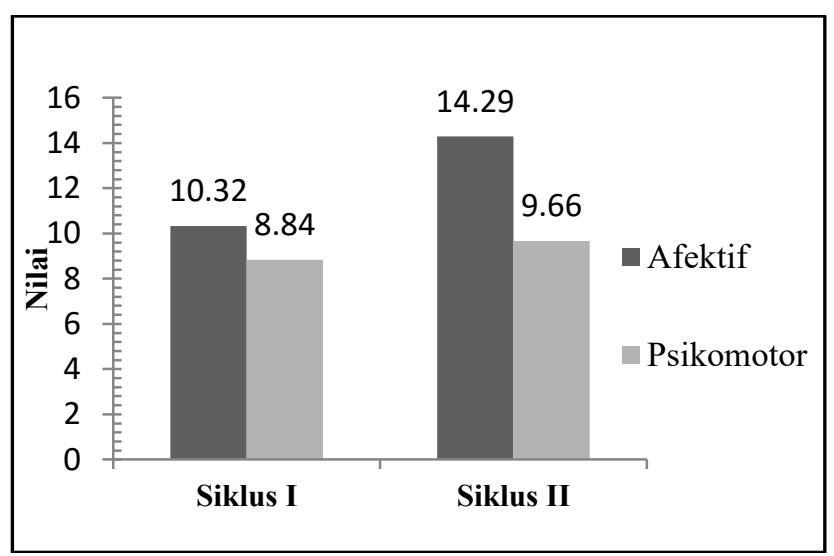

Gambar 1.3Diagram Hasil Belajar Ranah Afektif dan Psikomotor Siklus I dan Siklus II

penyelidikan dan bekerja sama dengan teman kelompoknya sehingga masih terdapat siswa yang sifatnya individual dalam melakukan kegiatan praktikum. Siswa juga belum memiliki rasa percaya diri untuk mempresentasikan hasil karya kelompok mereka karena belum terbiasa tampil di hadapan teman-temannya. Masih ada siswa yang tidak mendengarkan analisis dan evaluasi mengenai pemecahan masalah yang dijelaskan oleh guru.

Selain itu, guru masih belum melakukan tahaptahap pembelajaran secara maksimal dan masih ada tahapan pembelajaran Quantum yang tidak dilakukan oleh guru seperti guru tidak menjelaskan terlebih dahulu tujuan pem-belajaran yang ingin dicapai. Guru juga tidak memberikan kesempatan yang lebih banyak kepada siswa untuk bertanya mengenai konsep dari materi yang dipelajari. Akan tetapi, 
dilakukan perbaikan-perbaikan untuk diterapkan pada siklus II.

Setelah dilakukan perbaikan-perbaikan pada siklus II, diperoleh data hasil belajar siswa yang mengalami peningkatan yakni nilai rata-ratanya 78,10 dengan ketuntasan klasikal 89,19\% begitu pula data rata-rata aktivitas belajar siswa mengalami peningkatan yakni pada siklus I sebesar 11 dan pada siklus II sebesar 14,6. Data hasil aktivitas belajar siswa siklus II tersebut berada pada kategori aktif karena ada pada rentang nilai $14,58 \leq \bar{x}<18,74$. Dari hasil ini terlihat bahwa hasil belajar siswa sudah mencapai indikator keberhasilan karena siswa yang memperoleh nilai $\geq 75$ berada di atas $85 \%$ dan aktivitas belajar siswa juga sudah mencapai indikator keberhasilan karena nilainya berada pada kategori aktif. Karena aktivitas dan hasil belajar siswa sudah mencapai indikator keberhasilan, maka penelitian ini hanya sampai pada siklus II.

Berdasarkan hasil yang telah diperoleh, terlihat bahwa penerapan model pembelajaran Quantum dengan metode Diskusi memberikan dampak positif bagi siswa kelas VIII $_{5}$. Kegiatan pembelajaran yang diterapkan menuntut siswa untuk lebih bersemangat belajar terutama dalam kegiatan praktikum. Siswa yang sebelumnya jarang aktif dalam praktikum, pada penelitian ini dituntut untuk bersemangat menemukan konsep fisika dengan cara yang menyenangkan. Selain itu, siswa juga tidak lagi hanya duduk mendengarkan penjelasan guru, melainkan turut serta dalam kegiatan presentasi agar siswa dapat terampil berbicara di depan kelas.

Melalui model pembelajaran Quantum metode Diskusi yang diterapkan guru, siswa dapat mengembangkan keterampilan berpikir siswa sehingga memudahkan dalam proses belajar. Hal ini sesuai dengan pendapat seorang ahli yang mengatakan bahwa model pembelajaran Quantum merupakan cara baru yang memudahkan proses belajar, yang memadukan unsur seni dan pencapaian yang terarah untuk segala mata pelajaran [5].

Tidak hanya kemampuan kognitif siswa saja yang mengalami peningkatan atau perkembangan setelah diterapkannya model pembelajaran Quantum, melainkan kemampuan afektif dan psikomotornya seperti kemampuan siswa dalam berdiskusi, berkomunikasi, bekerjasama dalam memecahkan suatu persoalan sampai kemampuan siswa dalam melakukan percobaan atau penyelidikan. Hasil ini terlihat pada penelitian di SMPN 2 Lingsar yang meneliti hasil belajar siswa pada ranah kognitif, afektif, dan psikomotor dengan menerapkan model pembelajaran Quantum metode Diskusi. Selain itu juga pernyataan ini sesuai dengan penelitian yang dilakukan De'Porter, Reardon, dan Nourie [6] bahwa model pembelajaran Quantum mampu 68\% meningkatkan motivasi belajar, 73\% meningkatkan skor/nilai, 81\% meningkatkan rasa percaya diri, 84\% me-ningkatkan harga diri, dan 98\% melanjutkan penggunaan keterampilan [5].

Pada penelitian Sitti Hasnidar [7] bahwa hasil belajar dapat meningkat dengan model Quantum tipe VAK (Visual, Auditory, Kinesthetic) dalam 2 siklus dan pada setiap siklus selalu mengalami peningkatan hasil yang cukup drastis yaitu dari 34,48\% setelah pretes sampai $93,10 \%$ pada postes. Sedangkan penelitian yang dilakukan oleh $\mathrm{M}$. Bahaddin dan Yusuf [8] bahwa pendekatan pembelajaran Quantum dapat meningkatkan daya ingat (Retention), Attitude (Aktivitas), dan prestasi sains.

Berdasarkan hasil penelitian dan pembahasan di atas, bahwa aktivitas dan hasil belajar siswa mengalami peningkatan dari siklus I ke siklus II dan mencapai indikator keberhasilan pada siklus II. Dengan demikian, penerapan model pembelajaran Quantum metode diskusi pada materi Indra Penglihatan dan alat Optik dapat meningkatkan aktivitas dan hasil belajar fisika siswa SMPN 2 lingsar tahun ajaran 2014/2015.

\section{Penutup}

Penerapan model pembelajaran quantum dengan metode diskusi dapat meningkatkan aktivitas dan hasil belajar fisika siswa pada materi indra penglihatan dan alat optik di kelas $\mathrm{VIII}_{5}$ SMPN 2 Lingsar tahun ajaran 2014/2015. Peningkatan aktivitas siswa terlihat pada siklus I, dimana pada siklus I aktivitas siswa berada pada kriteria cukup aktif dengan skor rata-rata 11 dan pada siklus II aktivitas siswa mengalami peningkatan dari cukup aktif menjadi aktif dengan skor rata-rata 14,2. Penerapan model pembelajaran quantum dengan metode diskusi juga meningkatkan hasil belajar fisika siswa yaitu terlihat pada nilai rata-rata kelas dan ketuntasan klasikal dari siklus I dengan nilai rata-rata kelas sebesar 73,95 dan ketuntasan klasikal sebesar $78,95 \%$, pada siklus II nilai rata-rata kelas sebesar 78,10 dan ketuntasan klasikal sebesar 89,19\%.

Adapun saran-saran yang dapat diberikan adalah sebagai berikut: (a) Alokasi waktu diatur sebaik mungkin sehingga setiap tahap kegiatan berjalan dengan baik; (b) Pengelolaan kelas dan pengaturan kelompok yang baik; (c) Diperlukan bimbingan dan arahan dari guru pada saat kegiatan siswa melakukan percobaan; (d) Penggunaan model pembelajaran Quantum dengan metode Diskusi sebagai sebagai metode alternatif untuk meningkatkan hasil belajar siswa pada mata pelajaran yang lain; (e) Bagi siswa, diharapkan dapat menerapkan model pembelajaran Quantum dengan metode Diskusi untuk meningkatkan aktivitas siswa yang lebih tinggi sehingga dapat memunculkan kepercayaan diri dan motivasi dalam belajar fisika. 


\section{REFERENSI}

[1] Simarmata, R. R. R. 2014. Implementasi Model Pembelajaran Quantum Teaching dalam Peningkatan Hasil Belajar Fisika Materi Pokok Fluida di Kelas XI IPA-3 SMA Negeri 1 Hamparan Perak. Jurnal saintech 6 (2): 26-33.

[2] Juliani, R. dan Rahmatsyah. 2012. Penerapan Metode Quantum Teaching pada Mata Kuliah Pengukuran dan Alat Ukur Fisika Mahasiswa Semester I Jurusan Fisika FMIPA UNIMED. Jurnal Online Pendidikan Fisika 1 (1): 49-60.

[3] Arikunto, S. dan Suhardjono, S. 2012. Penelitian Tindak Kelas. Jakarta : Bumi Aksara.

[4] Nurkancana, W. dan Sunartana, PPN. 1990. Evaluasi hasil Belajar. Surabaya: Usaha Nasional.

[5] Wena, M. 2009. Strategi pembelajaran Inovatif Kontemporer. Jakarta: PT Bumi Aksara.

[6] De'Porter, B., Reardon, M., Nourie Singer, S. 2010. Quantum Teaching. Bandung: Kaifa PT Mizan pustaka.
[7] Hasnidar, Sitti. 2014. Quantum Learning Model Application Type VAK (Visual, Auditory, Kinesthetic) Results to Improve Student Learning Class XI SMA IA4 8 Banda Aceh Hydrolysis in Salt Content. The $5^{\text {th }}$ International Conference on Science Education and Teacher Profesional Development: 100-107.

[8] Bahaddin, M. dan Yusuf. 2014. An Investigation the Effect of Quantum Learning Approach on Primary School $7^{\text {th }}$ Grade Students' Science Achievement, Retention, and Attitude. Educational research Association the International Journal of Research in Teacher Education 5 (2): 11-23.

\section{Bigografi PenUlis}

Ibrohim Mirgoni, lahir di Selong, Lombok Timur, tanggal 01 Januari 1992. Penulis menyelesaikan bangku pendidikan SD, SMP, dan SMA di Selong. Kemudian, melanjutkan studinya di Universitas Mataram pada FKIP mengambil Program Studi Pendidikan Fisika dan lulus pada tahun 2015. 